\title{
The new coronavirus that came from the East: analysis of the initial epidemic in Mexico
}

José M. Ornelas-Aguirre*

Universidad de Sonora, Department of Health Sciences, Sonora, Mexico

\begin{abstract}
Introduction: As of March 23, 2020, suspension of non-essential activities was declared in Mexico throughout the country in order to mitigate the spread of the COVID-19 pandemic. Objective: To analyze data on the first 1,510 laboratory-confirmed cases of COVID-19 in Mexico, and to describe the geographical distribution of the disease and its transmission dynamics. Method: Description of the first COVID-19 cases with real-time RT-PCR-positive test, as well as evaluation of epidemiological measures, cumulative incidence, rate of transmission, and mortality and lethality rates during the first month of the epidemic. Results: Average age was 43 years, and $58 \%$ were males; $44 \%$ of initial cases were imported. Lethality in the population during the first month went from 1.08 to 3.97 per 100 cases; however, the trend is linear and similar to that observed in Europe. Conclusions: In Mexico, social distancing is being applied, but studies are still required on the dynamics of the epidemic, person-to-person transmission, incidence of subclinical infections, and patient survival.
\end{abstract}

KEY WORDS: Human coronavirus. SARS-CoV-2. Respiratory tract infections. Respiratory viruses.

\section{El nuevo coronavirus que llegó de Oriente: análisis de la epidemia inicial en México}

\section{Resumen}

Introducción: A partir del 23 de marzo de 2020, en México se declaró la suspensión de actividades no esenciales en todo el país para mitigar la diseminación de la pandemia de COVID-19. Objetivo: Analizar los datos sobre los primeros 1510 casos de COVID-19 confirmados por laboratorio en México, describir la distribución geográfica de la enfermedad y su dinámica de transmisión. Método: Descripción de los primeros casos de COVID-19 con prueba positiva de RT-PCR en tiempo real, así como evaluación de las medidas epidemiológicas, incidencia acumulada, razón de contagios y tasas de mortalidad y letalidad durante el primer mes de la epidemia. Resultados: La edad promedio fue de 43 años y 58 \% fue del sexo masculino; $44 \%$ de los casos iniciales fue importado. La letalidad en la población durante el primer mes pasó de 1.08 a 3.97 por 100 casos; sin embargo, la tendencia es lineal y similar a la observada en Europa. Conclusiones: En México se está aplicando el distanciamiento social, pero aún se requieren estudios sobre la dinámica de la epidemia, la transmisión de persona a persona, la incidencia de infecciones subclínicas y la supervivencia de los enfermos.

PALABRAS CLAVE: Coronavirus humano. SARS-CoV-2. Infecciones del tracto respiratorio. Virus respiratorios.

\footnotetext{
Correspondence:

*José M. Ornelas-Aguirre

E-mail: jmoapat@gmail.com

Gac Med Mex. 2020;156:208-216

Contents available at PubMed

www.gacetamedicademexico.com

0016-3813/С 2020 Academia Nacional de Medicina de México, A.C.. Published by Permanyer. This is an open access article under the CC BY-NC-ND license (http://creativecommons.org/licenses/by-nc-nd/4.0/).
} 


\section{Introduction}

A new virus, severe acute respiratory syndrome coronavirus 2 (SARS-CoV-2), was identified in January 2020 as the cause of a series of pneumonia cases initially detected in the city of Wuhan, Hubei Province, China. ${ }^{1}$ Shortly, SARS-CoV-2 disease has spread all over the world. ${ }^{2}$ It was not until March that the spread of COVID-19 was recognized by the World Health Organization as a pandemic. ${ }^{3}$ At the time of this report, more than 130,000 people have become infected in more than 100 countries, and the mortality rate went from 2 to $4 \%$ in a short time.

Coronaviruses are members of the Coronavirinae subfamily of the Coronaviridae family, and of the Nidovirales order (according to the International Committee on Taxonomy of Viruses classification). This subfamily consists of four genera: alphacoronavirus, betacoronavirus, gammacoronavirus, and deltacoronavirus, depending on their phylogenetic relationships and genomic structures. The two highly pathogenic viruses, SARS-CoV and MERS-CoV, cause severe respiratory syndrome in humans, and the other four human coronaviruses (HCoV-NL63, HCoV-229E, $\mathrm{HCoV}-\mathrm{OC} 43$, and HKU1) only induce mild upper respiratory diseases in immunocompetent hosts, although they can cause serious infections in infants, young children, and older people. ${ }^{4,5}$

SARS-CoV was the causative agent of severe acute respiratory syndrome outbreaks in 2002 and 2003 in the Guangdong province, China, with a lethality of 10 $\% .{ }^{6}$ Ten years later, MERS-Cov was the cause of Middle East respiratory syndrome (MERS-CoV), which has become a global health problem since 2012. ${ }^{7}$ On that occasion, it affected more than 2,000 people in 27 countries of four continents, with an average lethality of $34 \%$. In the Middle East, MERS-CoV epicenter was Saudi Arabia, ${ }^{8}$ a country to which millions of Muslims from all over the world travel annually to make the pilgrimage to Mecca (hajj), a tradition that contributed to global distribution of the virus. MERS$\mathrm{CoV}$ infection is transmitted from animals to humans and from humans to humans. ${ }^{9}$ Evidence shows that bats helped the spread of SARS-CoV ${ }^{10}$ and MERS$\mathrm{CoV}^{11,12}$ as the original host species. The main cause of the occurrence of MERS-CoV infections is exposure to animals, mainly to bats and camels, which can act as an intermediate host. ${ }^{4,13}$

We currently know that SARS-CoV uses angiotensin II converting enzyme receptor as a binding site to infect ciliated bronchial epithelial cells and type II pneumocytes, ${ }^{14}$ while MERS-CoV uses the dipeptidyl peptidase receptor 4 to infect non-ciliated bronchial epithelial cells and type II pneumocytes. ${ }^{15}$

In numerous countries, a desperate response has been given to get health systems ready and confront this unprecedented challenge. Unfortunately, China, Iran and Italy did not have the opportunity to prepare and resist the rush of sick people seeking medical attention, which caused more than 100,000 confirmed infections and 4,000 deaths from COVID-19. ${ }^{16}$ Containment measures implemented in China have reduced the occurrence of new cases by $90 \%$.

With the identification of the first cases in Mexico, as of March 20, the federal government declared the suspension of educational activities in public and private systems and requested to postpone massive events involving more than 5,000 people. On March 23, the "Healthy Distance" ("Sana Distancia") campaign was launched, which seeks to reduce contact between people by temporarily suspending non-essential activities in the public, social and private sectors. The campaign includes the following strategies:

- Promotion of frequent hand washing.

- Distant greeting.

- Diffusion of the habit of sneezing or coughing into the elbow.

- Domiciliary isolation of sick people.

- Protection, isolation and care of older adults.

The purpose of this document is to analyze data on the first 1,510 laboratory-confirmed COVID-19 cases in Mexico, describe the geographical and age distribution, and the dynamics of transmission.

\section{Method}

Based on information published by the World Health Organization (www.who.int), the Center for Science and Systems Engineering at Johns Hopkins University in Maryland, United States (coronavirus.jhu.edu) and the Unit of Epidemiological and Sanitary Intelligence of the Ministry of Health of Mexico (www.coronavirus. gob.mx), an analytical, cross-sectional study was carried out. Cases are reported as positive for SARSCoV-2 infection when they meet the following criteria: clinical symptoms (fever, cough, malaise) and positive test by real-time RT-PCR for COVID-19 at any of the national laboratories authorized for this purpose. The following variables were recorded for this study:

- Date of the case report.

- Date of symptom onset. 


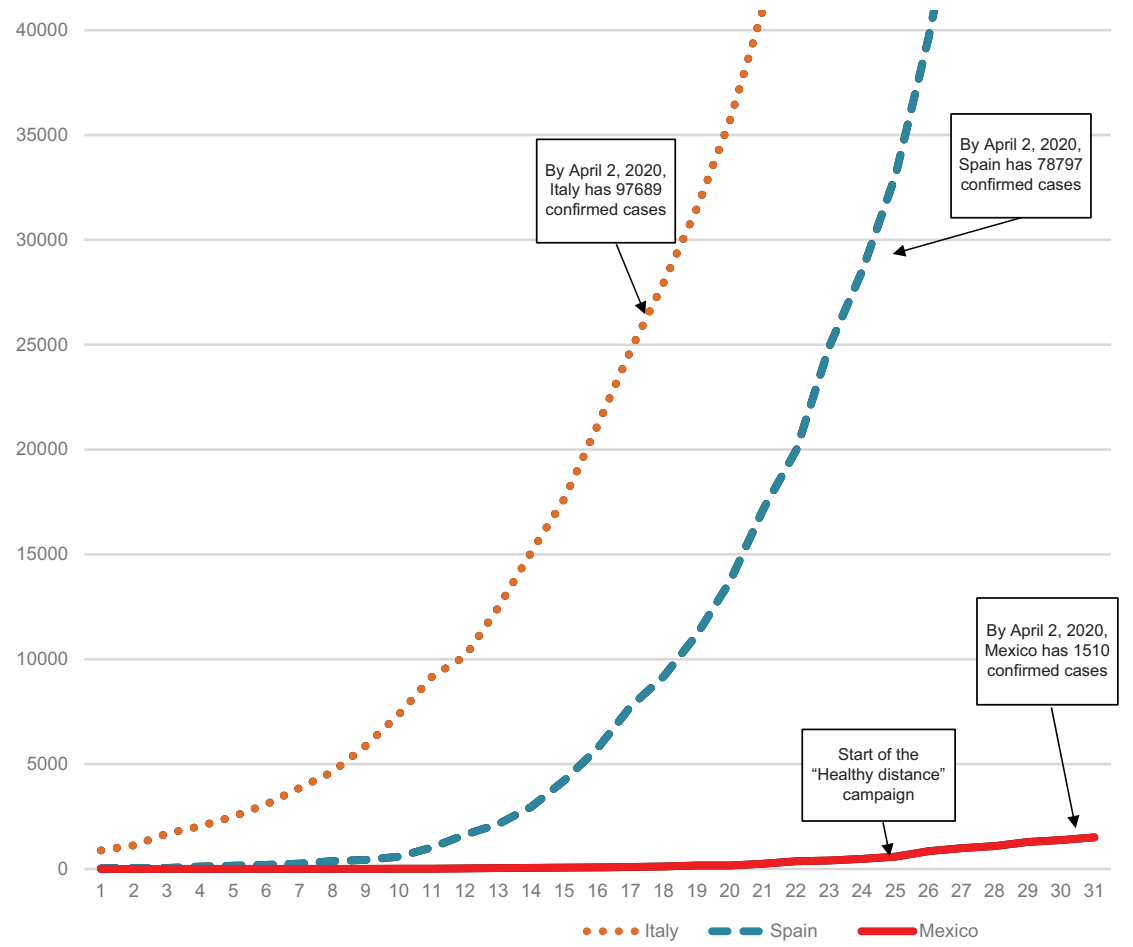

Figure 1. COVID-19 new cases in Italy and Spain in comparison with Mexico in the first month after the first cases were recorded in the latter country.

- Date of diagnosis.

- State of the republic where the case report was generated.

- Gender.

- Age.

- Origin of the cases that got infected abroad.

With the statistical program SPSS version 21, a database was constructed for descriptive analysis, with measures of central tendency and dispersion, of the number of patients, origin of the "imported" cases and distribution in the country. Epidemiological measures such as cumulative incidence, rate of infection, mortality and lethality rates were used to determine the evolution of the epidemic during the first month of evolution in the country. For the variables described in frequency, $95 \%$ confidence intervals were calculated. Scatter plots were generated.

\section{Results}

Between February 29 and April 2, 2020, 1,510 COVID-19-positive cases were reported in Mexico, out of which 872 cases were of the male gender (58\%, $95 \% \mathrm{Cl}=55-61)$ and 638 were females $(42 \%, 95 \%$ $\mathrm{Cl}=38-46)$. Figure 1 describes the comparison of new COVID-19 cases in Italy, Spain and Mexico for the referred period.

Age of the cases ranged from 0 to 89 years, with an average of $43 \pm 16$ years; the percentile calculation showed that $25 \%$ of the cases (P25) were younger than 31 years, $50 \%$ (P50), younger than 42 years, and $75 \%$ (P75) were younger than 54 years. The results show a high prevalence of the disease in an economically active young population, at least 10 years younger than the Chinese population, $5 \%$ of the cases were even younger than 20 years, while only $10 \%$ of cases were older than 65 years (highest-risk population). Figure 2 describes COVID-19-positive cases age distribution during the first month of the epidemic in Mexico according to their frequency.

Forty-four percent of the cases that started the epidemic in Mexico came from Europe and the United States: 296 cases from the United States (45\%, $95 \%$ $\mathrm{Cl}=39-51) ; 272$ cases from Spain $(41 \%, 95 \% \mathrm{Cl}=$ $35-47)$. The rest of the countries and their impact on total onset of the epidemic are described in table 1 and figure 3 .

When analyzing the incidence of cases by states of the country, most were identified in Mexico City $(n=346$, 


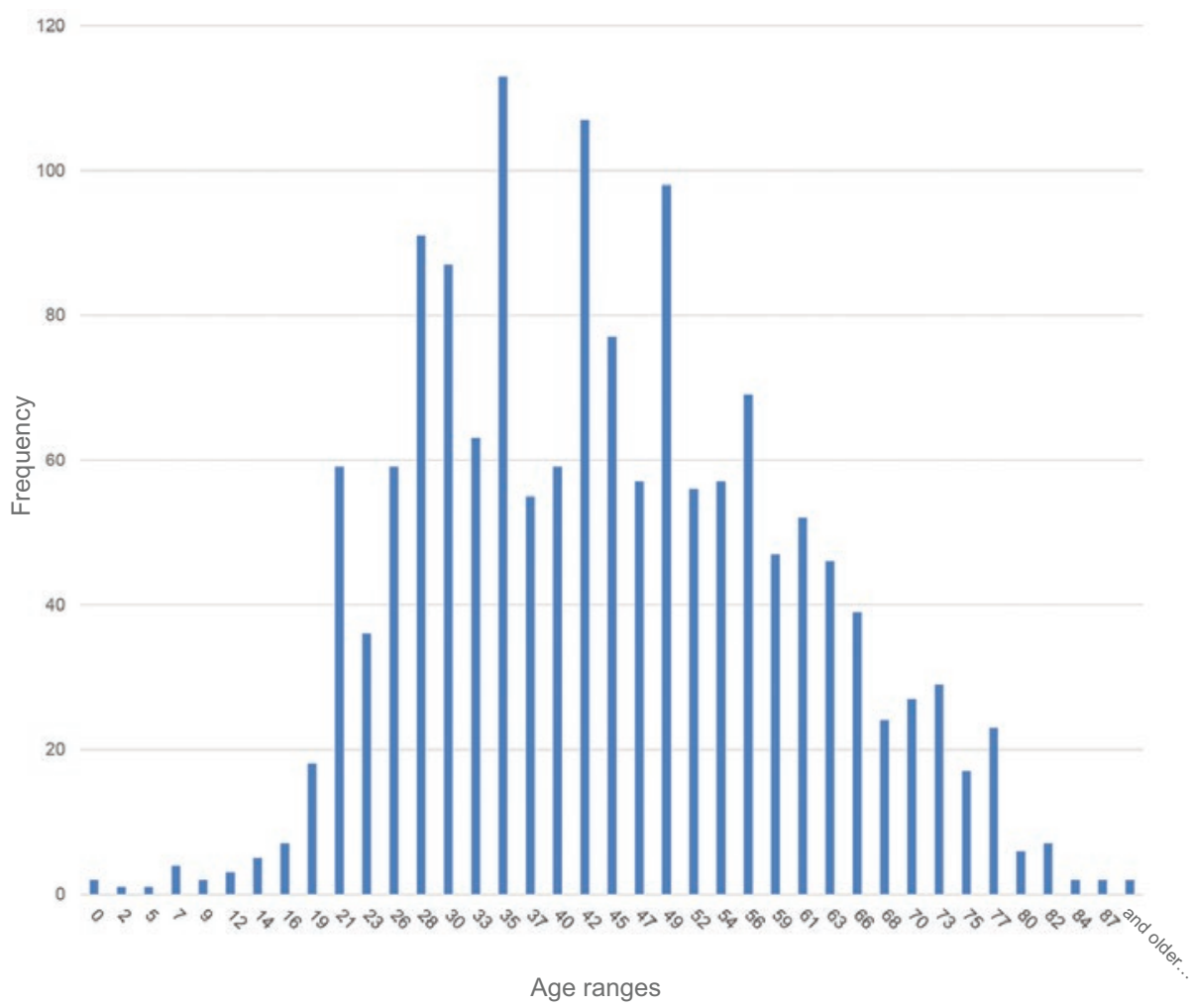

Figure 2. COVID-19-positive cases by age ranges during the first month of the pandemic in Mexico.

Table 1. Origin of the 661 cases that started the spread of COVID19 during the first month of the pandemic in Mexico

\begin{tabular}{|l|c|c|c|}
\hline & n & $\%$ & $95 \%$ Cl \\
\hline United States & 296 & 45 & 39 to 51 \\
\hline Spain & 272 & 41 & 35 a 47 \\
\hline France & 54 & 8 & 1 a 15 \\
\hline Italy & 24 & 3.6 & -4 a 11 \\
\hline Germany & 13 & 1.9 & -6 a 9 \\
\hline $\begin{array}{l}\text { Singapore } \\
\text { 95 \% Cl = 95 \% confidence interval. Source: Unidad de Inteligencia Epidemiológica y } \\
\text { Sanitaria de la Secretaría de Salud de México (www.coronavirus.gob.mx). }\end{array}$
\end{tabular}

$22.9 \%)$, State of Mexico $(\mathrm{n}=175,11.6 \%)$, Puebla $(n=102,6.7 \%)$, Jalisco $(n=113,7.4 \%)$ and Nuevo León $(n=79,5.2 \%)$. The remaining states had approximately 50 cases or less. An important aspect is the rate of infection directly related to the spread of the virus in the local population by cases infected abroad. Among the states with an accelerated infection rate, Michoacán (5.7), Sinaloa (4.8), Tabasco (4.1) and Coahuila (3.0) were identified. The incidence and rate of transmission of COVID-19-positive cases during the first month of the pandemic in Mexico are presented in table 2.

As for COVID-19-associated mortality, unlike Italy, which in the analyzed period went from 2.36 to 11.04 per 100 cases, and Spain, which went from 0.51 to 8.28 per 100 cases, Mexico was observed to have a slower evolution: it went from 1.08 to 3.97 per 100 cases, although the trend was linear and similar to that recorded in European countries, which indicates that if the required epidemiological actions are not carried out, the result could be similar to that of Spain or the United States.

The incidence of mortality has been higher in Mexico City ( 15 cases), with a cumulative incidence of 42.6 and a lethality of 3.9 per 100 cases. However, the states of the country that had the highest lethality were Morelos (25.0), Zacatecas (14.3), Durango (12.5), Nayarit (12.5), Hidalgo (10.0), Sinaloa (9.8), Baja California (9.6) and Baja California Sur (9.5), higher than global disease lethality: 4.7 per 100 cases. Deaths, cumulative incidence, mortality rate, and lethality of COVID-19-positive cases during the first month of the pandemic in Mexico in comparison with Italy and Spain are described in table 3 and figure 4. 


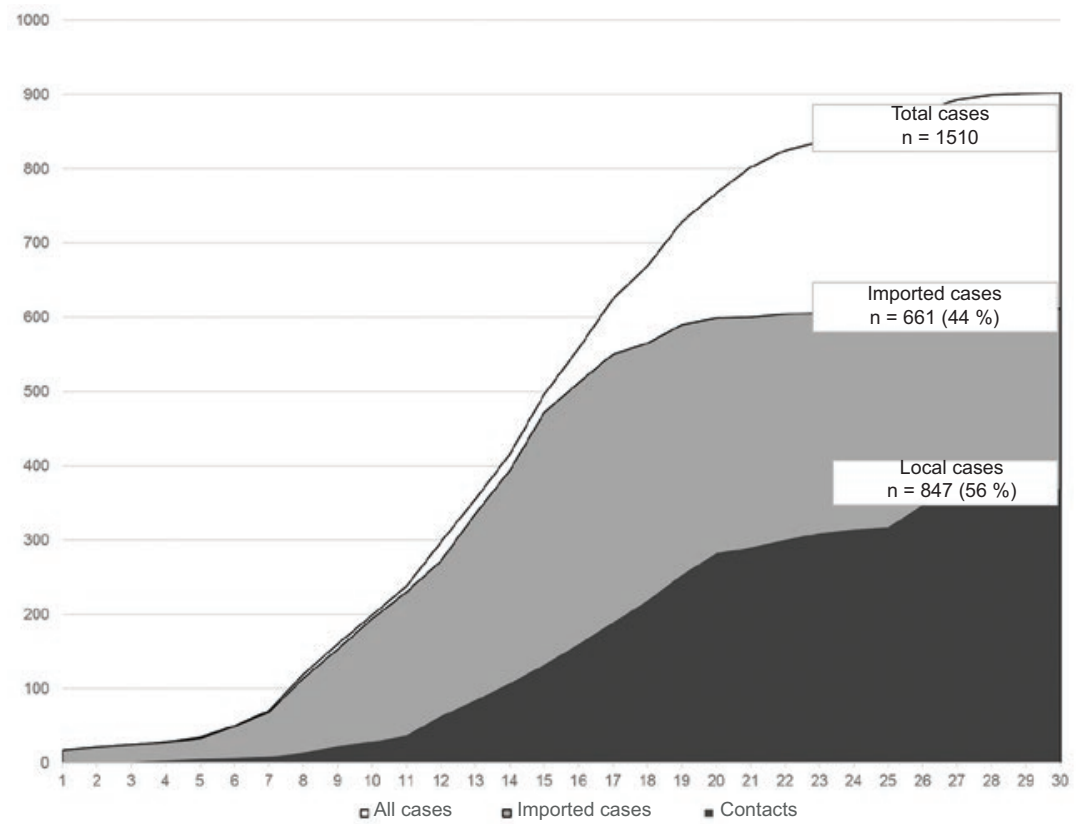

Figure 3. Cumulative number of COVID-19-positive cases during the first month of the pandemic in Mexico according to their origin.

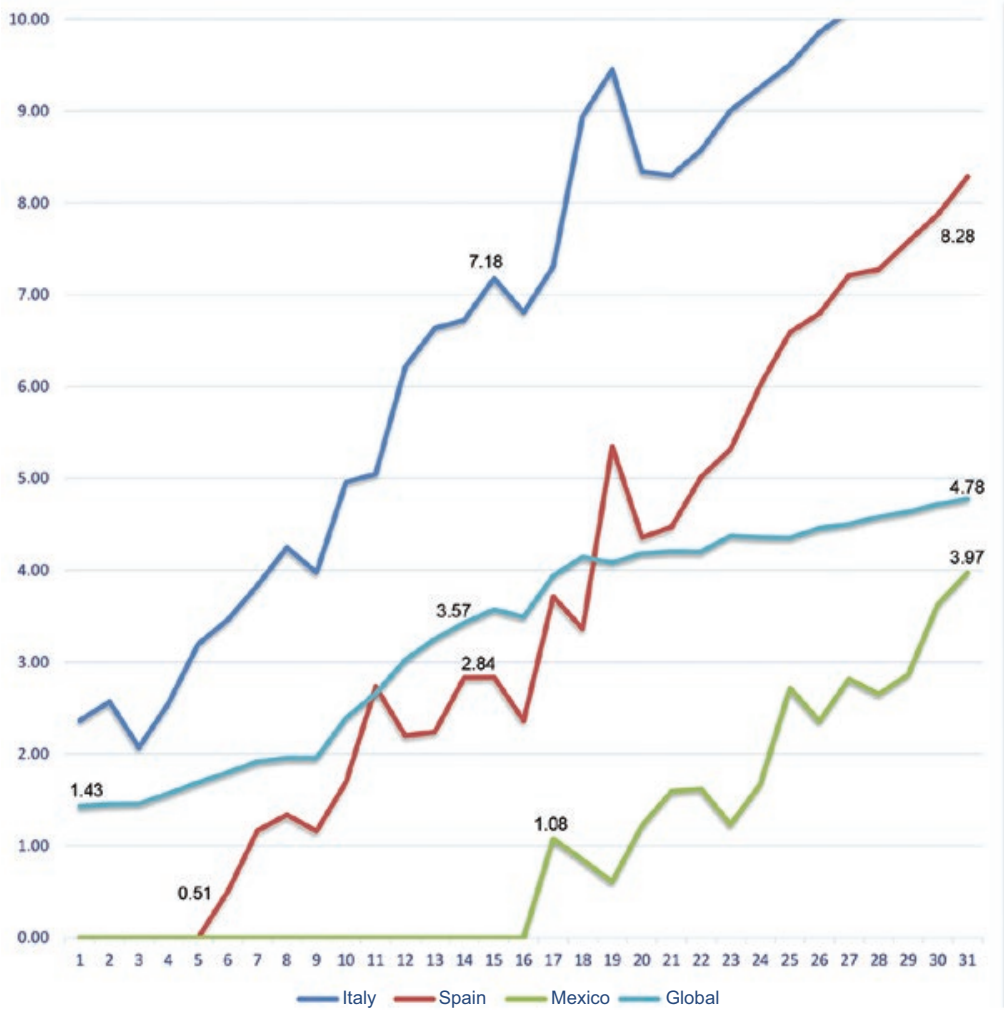

Figure 4. COVID-19 lethality in Italy and Spain in comparison with Mexico in the first month after the pandemic started in the latter country.

\section{Discussion}

This study presents a summary of epidemiological information during the first month of the COVID-19 epidemic in Mexico. This disease arrived in a very short time at two main fronts, the United States (which at the time of this report is the first focus of infection worldwide) and Spain, the health system of which has collapsed. 
Table 2. COVID-19-positive cases incidence and rate of transmission during the first month of the pandemic in Mexico

\begin{tabular}{|c|c|c|c|c|c|c|c|}
\hline \multirow[t]{2}{*}{ State } & \multicolumn{2}{|c|}{ Imported cases } & \multicolumn{2}{|c|}{ Local cases (contacts) } & \multicolumn{2}{|c|}{ Total } & \multirow[t]{2}{*}{ Rate of transmission } \\
\hline & $\mathrm{n}$ & $\%$ & $\mathrm{n}$ & $\%$ & $\mathrm{n}$ & $\%$ & \\
\hline Mexico City & 162 & 24.5 & 184 & 21.7 & 346 & 22.9 & 1.12 \\
\hline Jalisco & 65 & 9.8 & 48 & 5.7 & 113 & 7.4 & 0.73 \\
\hline Nuevo León & 56 & 8.5 & 23 & 2.7 & 79 & 5.2 & 0.41 \\
\hline State of Mexico & 54 & 8.2 & 121 & 14.3 & 175 & 11.6 & 2.24 \\
\hline Puebla & 40 & 6.1 & 62 & 7.3 & 102 & 6.7 & 1.55 \\
\hline Guanajuato & 35 & 5.3 & 24 & 2.8 & 59 & 3.9 & 0.68 \\
\hline Quintana Roo & 26 & 3.9 & 30 & 3.5 & 56 & 3.7 & 1.1 \\
\hline Yucatán & 24 & 3.6 & 30 & 3.5 & 54 & 3.5 & 1.2 \\
\hline San Luis Potosí & 18 & 2.7 & 12 & 1.4 & 30 & 1.9 & 0.6 \\
\hline Veracruz & 17 & 2.6 & 20 & 2.4 & 37 & 2.4 & 1.1 \\
\hline Querétaro & 17 & 2.6 & 16 & 1.9 & 33 & 2.1 & 0.9 \\
\hline Baja California & 16 & 2.4 & 22 & 2.6 & 38 & 2.5 & 1.3 \\
\hline Aguascalientes & 14 & 2.1 & 28 & 3.3 & 42 & 2.7 & 2.0 \\
\hline Sonora & 13 & 2.0 & 7 & 0.8 & 20 & 1.3 & 0.5 \\
\hline Coahuila & 13 & 2.0 & 40 & 4.7 & 53 & 3.5 & 3.0 \\
\hline Tabasco & 11 & 1.7 & 46 & 5.4 & 57 & 3.7 & 4.1 \\
\hline Guerrero & 8 & 1.2 & 11 & 1.3 & 19 & 1.2 & 1.3 \\
\hline Hidalgo & 8 & 1.2 & 13 & 1.5 & 21 & 1.3 & 1.6 \\
\hline Tamaulipas & 7 & 1.1 & 2 & 0.2 & 9 & 0.5 & 0.2 \\
\hline Oaxaca & 7 & 1.1 & 15 & 1.8 & 22 & 1.4 & 2.1 \\
\hline Chiapas & 7 & 1.1 & 6 & 0.7 & 13 & 0.8 & 0.8 \\
\hline Chihuahua & 6 & 0.9 & 4 & 0.5 & 10 & 0.6 & 0.6 \\
\hline Sinaloa & 6 & 0.9 & 29 & 3.4 & 35 & 2.3 & 4.8 \\
\hline Baja California Sur & 5 & 0.8 & 13 & 1.5 & 18 & 1.1 & 2.6 \\
\hline Durango & 5 & 0.8 & 2 & 0.2 & 7 & 0.4 & 0.4 \\
\hline Campeche & 4 & 0.6 & 2 & 0.2 & 6 & 0.3 & 0.5 \\
\hline Michoacán & 4 & 0.6 & 23 & 2.7 & 27 & 1.7 & 5.7 \\
\hline Morelos & 4 & 0.6 & 5 & 0.6 & 9 & 0.5 & 1.2 \\
\hline Nayarit & 3 & 0.5 & 4 & 0.5 & 7 & 0.4 & 1.3 \\
\hline Colima & 2 & 0.3 & 0 & -- & 2 & 0.1 & -- \\
\hline Tlaxcala & 2 & 0.3 & 3 & 0.4 & 5 & 0.3 & 1.5 \\
\hline Zacatecas & 2 & 0.3 & 4 & 0.5 & 6 & 0.4 & 2.0 \\
\hline
\end{tabular}

Source: Unidad de Inteligencia Epidemiológica y Sanitaria de la Secretaría de Salud de México (www.coronavirus. gob.mx). Downloaded on April 2, 2020.

According to Mexico's geographical distribution, the highest incidence of cases was observed in the country's central states, where there is a higher flow of international travelers and higher population density, and the disease is gradually spreading throughout the country. The debate on the advisability of early closure 
Table 3. Deaths, cumulative incidence, mortality rate and lethality of COVID-19-positive cases during the first month of the pandemic in Mexico

\begin{tabular}{|c|c|c|c|c|c|}
\hline State & Non-fatal cases & Deaths & Cumulative incidence & Mortality rate & Lethality \\
\hline Mexico City & 369 & 15 & 42.6 & 1.7 & 3.9 \\
\hline Quintana Roo & 64 & 1 & 37.7 & 0.6 & 1.5 \\
\hline Aguascalientes & 48 & 0 & 33.5 & 0.0 & 0.0 \\
\hline Tabasco & 70 & 3 & 28.4 & 1.2 & 4.1 \\
\hline Yucatán & 59 & 0 & 26.1 & 0.0 & 0.0 \\
\hline Baja California Sur & 19 & 2 & 26.1 & 2.5 & 9.5 \\
\hline Coahuila & 67 & 3 & 21.7 & 0.9 & 4.3 \\
\hline Puebla & 108 & 1 & 16.5 & 0.2 & 0.9 \\
\hline Sinaloa & 46 & 5 & 16.2 & 1.6 & 9.8 \\
\hline Querétaro & 33 & 2 & 15.4 & 0.9 & 5.7 \\
\hline Nuevo León & 85 & 0 & 15.2 & 0.0 & 0.0 \\
\hline Baja California & 47 & 5 & 14.3 & 1.4 & 9.6 \\
\hline Jalisco & 110 & 6 & 13.8 & 0.7 & 5.2 \\
\hline San Luis Potosí & 33 & 2 & 12.2 & 0.7 & 5.7 \\
\hline State of Mexico & 176 & 1 & 10.2 & 0.1 & 0.6 \\
\hline Hidalgo & 27 & 3 & 9.7 & 1.0 & 10.0 \\
\hline Sonora & 28 & 0 & 9.1 & 0.0 & 0.0 \\
\hline Guanajuato & 52 & 0 & 8.3 & 0.0 & 0.0 \\
\hline Guerrero & 23 & 1 & 6.6 & 0.3 & 4.2 \\
\hline Nayarit & 7 & 1 & 6.2 & 0.8 & 12.5 \\
\hline Campeche & 6 & 0 & 6.0 & 0.0 & 0.0 \\
\hline Morelos & 9 & 3 & 5.9 & 1.5 & 25.0 \\
\hline Tlaxcala & 8 & 0 & 5.8 & 0.0 & 0.0 \\
\hline Oaxaca & 21 & 1 & 5.3 & 0.2 & 4.5 \\
\hline Colima & 4 & 0 & 5.1 & 0.0 & 0.0 \\
\hline Michoacán & 23 & 1 & 5.0 & 0.2 & 4.2 \\
\hline Tamaulipas & 16 & 0 & 4.4 & 0.0 & 0.0 \\
\hline Durango & 7 & 1 & 4.3 & 0.5 & 12.5 \\
\hline Zacatecas & 6 & 1 & 4.2 & 0.6 & 14.3 \\
\hline Veracruz & 33 & 2 & 4.1 & 0.2 & 5.7 \\
\hline Chihuahua & 12 & 0 & 3.2 & 0.0 & 0.0 \\
\hline Chiapas & 18 & 0 & 3.1 & 0.0 & 0.0 \\
\hline Total national & 1634 & 60 & 13.3 & 0.47 & 3.5 \\
\hline \multicolumn{6}{|c|}{$\begin{array}{l}95 \% \mathrm{Cl}=95 \% \text { confidence interval. Lethality higher than world average indicated in bold numbers (approximately 5.0). Source: Unidad de Inteligencia Epidemiológica y Sanitaria de la } \\
\text { Secretaria de Salud de México (www.coronavirus.gob.mx). Downloaded on April 4, } 2020 \text {. }\end{array}$} \\
\hline
\end{tabular}


120 million inhabitants of Mexico, there would be a scenario of approximately 18 million patients seeking medical attention in gradual waves. That same study showed that $5 \%$ of cases were admitted to an intensive care unit, $2.3 \%$ required assisted mechanical ventilation and $1.4 \%$ died.

This leads to the projection that approximately 900,000 beds at intensive care units and 20,700 ventilators will be required in Mexico and that 12,600 deaths from COVID-19 might occur. Although these figures sound unlikely at this moment, the figures published by the World Health Organization (www. who.int) indicate that 14,681 patients have died in Italy and 10,935 in Spain. An advantage in Mexico is the younger age of the cases in comparison with China, where the average is 56 years (range 46 to $67) ;{ }^{19}$ moreover, $5 \%$ of cases in Mexico are younger than 20 years and only $10 \%$ are older than 65 years. However, it cannot be ignored that comorbidities (high blood pressure, obesity, diabetes mellitus and immunosuppression, among others) increase mortality, and that Mexico has a clear disadvantage in this regard. ${ }^{20}$

Early establishment of social distancing in Mexico was an adequate measure. According to studies carried out in China, the disease has a propagation speed among the population (R0) of $2.2(95 \% \mathrm{Cl}=1.4-3.9),{ }^{1}$ which is much higher than that of influenza $(\mathrm{R} 0=1.3),{ }^{21}$ and is a value that can be decreased with the isolation of positive cases.

With regard to lethality, analytical curves show a similar trend to those of Spain or Italy, but with a slower daily change. This means that the epidemic in Mexico will probably be slower and last longer, and the recommended measures should therefore be continued in the states of the country where the spread of the disease is more accelerated (infection rate). No country could face a disease that is transmitted so quickly without the effort of the population to stop the spread.

As weaknesses of this investigation, the type of study and the lack of follow-up of COVID-19 cases can be mentioned, which is information we did not have access to. Despite the above, the results provide an initial approach to the way the disease is distributed in Mexico.

\section{Conclusions}

In the worst case scenario, the evolution in Mexico of the COVID-19 pandemic could be similar to that of
Spain, which is a situation that can only be modified with efforts of the population, continuation of the social distancing strategies implemented by the Ministry of Health and with the identification of more effective control measures to reduce transmission in the community. In the future, studies could be carried out on the dynamics of the epidemic, person-to-person transmission in households and other settings, serological tests results to determine the incidence of subclinical infections (carriers of the disease) and patient survival in different types of population. It is difficult to define whether the hospital infrastructure in our country will be sufficient to contain the pandemic. In Mexico, the coin is still in the air.

\section{Conflict of interests}

The author declares that he has no conflicts of interest.

\section{Funding}

The author received no sponsorship to carry out this article.

\section{Ethical disclosures}

Protection of people and animals. The author declares that no experiments were performed on humans or animals for this study.

Confidentiality of data. The author declares that no patient data appear in this article.

Right to privacy and informed consent. The author declares that no patient data appear in this article.

\section{References}

1. Li Q, Guan X, Wu P, Wang X, Zhou L, Tong Y, et al. Early transmission dynamics in Wuhan, China, of novel coronavirus-infected pneumonia. N Engl J Med. 2020;382:1199-1207.

2. Remuzzi A, Remuzzi G. COVID-19 and Italy: What next? Lancet. 2020;2:10-13.

3. Cucinotta D, Vanelli M. WHO declares COVID-19 a pandemic. Acta Biomed. 2020:91:157-160.

4. Su S, Wong G, Shi W, Liu J, Lai ACK, Zhou J, et al. Epidemiology, genetic recombination, and pathogenesis of coronaviruses. Trends Microbiol. 2016:24:490-502.

5. Forni D, Cagliani R, Clerici M, Sironi M. Molecular evolution of human coronavirus genomes. Trends Microbiol. 2017;25:35-48.

6. Zhong NS, Zheng BJ, Li YM, Poon LLM, Xie ZH, Chan KH, et al. Epidemiology and cause of severe acute respiratory syndrome (SARS) in Guangdong, People's Republic of China, in February, 2003. Lancet. 2003;362:1353-1358.

7. Zaki AM, van Boheemen S, Bestebroer TM, Osterhaus ADME, Fouchier RAM. Isolation of a novel coronavirus from a man with pneumonia in Saudi Arabia. N Engl J Med. 2012;367:1814-1820.

8. Alqahtani AS, Rashid $\mathrm{H}$, Basyouni MH, Alhawassi TM, BinDhim NF Public response to MERS-CoV in the Middle East: iPhone survey in six countries. J Infect Public Health. 2017;10:534-540. 
9. Stoffberg S, Corman VM, Cottontail VM, Richards LR, Schoeman MC Drosten $\mathrm{C}$, et al. Close relative of human Middle East respiratory syndrome coronavirus in bat, South Africa. Emerg Infect Dis. 2013;19:1697-1699.

10. Ksiazek TG, Erdman D, Goldsmith CS, Zaki SR, Peret T, Emery S, et al. A novel coronavirus associated with severe acute respiratory syndrome. N. Engl. J. Med. 2003:348:1953-1966.

11. Ge X, Li J, Yang X, Chmura AA, Zhu G, Epstein H, et al. Isolation and characterization of a bat SARS-like coronavirus that uses the ACE2 receptor parts of the experiments and analyses HHS Public Access. Nature. 2013;503:535-538.

12. Nassar MS, Bakhrebah MA, Meo SA, Alsuabeyl MS, Zaher WA. Middle East Respiratory Syndrome Coronavirus (MERS-CoV) infection: epidemiology, pathogenesis and clinical characteristics. Eur Rev Med Pharmacol Sci. 2018;22:4956-4961.

13. Raj VS, Smits SL, Provacia LB, van den Brand JMA, Wiersma L, Ouwendijk WJD, et al. Adenosine deaminase acts as a natural antagonist for dipeptidyl peptidase 4-mediated entry of the Middle East respiratory syndrome coronavirus. J Virol. 2014;88:1834-1838.

14. Kuhn JH, Li W, Choe H, Farzan M. Angiotensin-converting enzyme 2: a functional receptor for SARS coronavirus. Cell Mol Life Sci. 2004;61:2738-2743.
15. Lu G, Hu Y, Wang Q, Qi J, Gao F, Li Y, et al. Molecular basis of binding between novel human coronavirus MERS-CoV and its receptor CD26. Nature. 2013;500:227-231.

16. Neher RA, Dyrdak R, Druelle V, Hodcroft EB, Albert J. Impact of seasonal forcing on a potential SARS-CoV-2 pandemic. medRxiv. 2020.

17. Guan WJ, Ni ZY, Hu Y, Liang WH, Ou CQ, He JX, et al. Clinical characteristics of coronavirus disease 2019 in China. N Engl J Med. 2020;1-13.

18. Wu Z, McGoogan JM. Characteristics of and important lessons from the coronavirus disease 2019 (COVID-19) outbreak in China: summary of a report of 72314 cases from the Chinese Center for Disease Control and Prevention. JAMA. 2020.

19. Zhou F, Yu T, Du R, Fan G, Liu Y, Liu Z, et al. Clinical course and risk factors for mortality of adult inpatients with COVID-19 in Wuhan, China: a retrospective cohort study. Lancet. 2020;395:1054-1062.

20. Villa AR, Escobedo MH, Méndez-Sánchez N. Estimación y proyección de la prevalencia de obesidad en México a través de la mortalidad por enfermedades asociadas. Gac Med Mex. 2004;140:21-26.

21. Ridenhour B, Kowalik JM, Shay DK. Unraveling R0: considerations for public health applications. Am J Public Health. 2018;108:S445-S454. 